mercury pump which made possible the evacuation of Swan's and Edison's electric glow lamps, Crookes's radiometer and Rontgen's apparatus, and for his improvements in explosives. In 1871 he took out patents for a class of explosives which were nonexplosive during manufacture, storage and transport, but for want of encouragement he allowed the patents to lapse. His explosive 'rack-a-rock' was used in $\mathbf{1 8 8 5}$ for removing the Flood Rock Reef which obstructed the entrance to New York Harbour at Hell Gate, some $300,000 \mathrm{lb}$. of the explosive being used. He also devised a U-tube for the determination of the density of liquids, introduced the use of a finely divided spray of water in the place of steam in sulphuric acid chambers and was the first to direct attention to the value of picric acid as an explosive.

\section{New Belgian Ascent into the Stratosphere}

Dr. Max Cosyns is to be warmly congratulated on his successful ascent into the stratosphere on August 18. The disaster of the two previous ascents had not deterred the chief actors in this from going forward with their preparations, for it will be remembered that the American ascent came to grief only so recently as July 28. Dr. Cosyns was accompanied on this ascent by M. van der Elst, and the project was under the auspices of the Belgian Fonds National de la Recherche Scientifique which gave the balloon its name $F . N . R . S$. It had a capacity of about $14,000 \mathrm{cu}$. metres and was provided with an aluminium gondola with special means of rapid exit. The motive of the flight was the investigation of the directive tendency of the cosmic radiation, and as a good landing has been made it is to be hoped that the records are safe. The ascent was made from Hour-Havenne in the valley of the Lesse in Belgian Luxembourg at 6.10 a.m. on Saturday in perfect weather conditions, and the descent at Zenavlje in Yugoslavia at 9.30 p.m. on the same day. The height reached, as reported in the daily newspapers, was about 10 miles. Though this does not constitute a record for height, the recent aeroplane work of Blackett and Gilbert in Great Britain at comparatively low altitudes shows the value of such data as may be obtained in this manner in resolving the problem of the directive tendency of the cosmic radiation. A further point of interest is the fact that the balloon covered a distance of about 1,000 miles in a general southeasterly direction during a period of 15 hours. This would indicate a very high wind velocity at high altitudes.

\section{Cambridge Lake Rudolf Rift Valley Expedition}

THIs expedition has now been in the field some eight months, and we regret to report that on August 14 two members-Dr. W. S. Dyson, naturalist; and Mr. W. H. D. Martin, surveyor-are reported missing on South Island. There are three uninhabited volcanic islands in the lake : Central Island, studied by the Cambridge Expedition of 1930-31, North Island, visited in 1932 and South (Hohnel) Island, which has remained unknown since it was roughly mapped from the mainland during the original exploratorv journey by
Teleki and von Höhnel in 1885. Its study was a particular object of this year's expedition, which has a folding boat and outboard motor for the purpose. The two men crossed the five miles of open water to the island about August 1, and after a fortnight in which prearranged signals were not received on the mainland, Mr. V. E. Fuchs, leader of the expedition, asked for Government assistance, if possible by aeroplane, to aid in the search. If the missing men are on the island they should have little difficulty in obtain. ing subsistence on fish; the water is potable though unpleasantly alkaline. Earlier in the year the expedition, which is mainly geological, proceeded up the west side of the lake with the view of going to the Omo River and excavating important bone beds en route. The Malembe triangle, where Kenya borders on the Sudan and Abyssinia, is somewhat unsettled and an armed guard had to be taken north from Lokitaung; this impeded the work, but valuable collections and surveys have been made. After returning south, the expedition moved to the southeast corner of the lake to study the eastern scarp of the rift valley, where high-level beaches were reported by the 1931 expedition. It was here that the unfortunate incident occurred.

\section{Gift to the University of Birmingham}

AT the meeting of the Court of Governors of the University of Birmingham in February, reference was made to the urgent need of further accommodation for the Department of Chemistry, but it was pointed out that the financial commitments incurred in the building of the new Medical School were such as to make the desired addition to the chemistry building impossible for the present. The difficulty has now been solved by the generous gift of $£ 45,000$ by Mr. A. E. Hills, a Birmingham tube manufacturer, for the specific purpose of erecting an additional block of buildings for the Department of Chemistry. In his letter to the Pro-Chancellor, Mr. Hills says : "For some time past I have had in my mind the desire to assist the higher education of those likely to be engaged in industry in Birmingham and the Midlands, with which I have been closely connected in my business life. I have come to the conclusion that I can best do so by helping the University in one of its scientific departments which is in need of extension. . . . It seems to me that the department most overcrowded and badly housed is that of Chemistry. Much of its work is being carried on in wooden huts which are inadequate and are becoming dangerous. The present Chemistry block is insufficient for the increasing number of students who come to it for the training in chemistry which forms a necessary part in practically all scientific careers, and also for those engaged in post-graduate research." It is understood that the new block will fill the gap between the existing chemistry and geological blocks, thus completing the western part of the architect's original scheme for the group of buildings.

\section{Edinburgh Geological Society}

BY the end of this year, the Edinburgh Geological Society will have been in existence for one hundred 